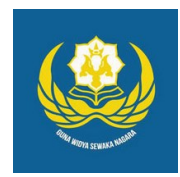

Jurnal Analogi Hukum

Journal Homepage: https://ejournal.warmadewa.ac.id/index.php/analogihukum

\title{
Pelaksanaan Perlindungan Hukum bagi Penyandang Disabilitas dalam Mendapatkan Pelayanan Publik di Kabupaten Tabanan
}

\author{
I Putu Sumardika*, I Wayan Wesna Astara dan I Nyoman Sutama \\ Universitas Warmadewa, Denpasar-Bali, Indonesia \\ *Pututude1206@gmail.com
}

\begin{abstract}
How To Cite:
Sumardika, I, P., Astara, I, W, W., Sutama, I, N. (2021). Pelaksanaan Perlindungan Hukum bagi Penyandang Disabilitas dalam Mendapatkan Pelayanan Publik di Kabupaten Tabanan. Jurnal Analogi Hukum. 3 (2). 170-176. Doi: https://doi.org/10.22225/ah.3.2.2021.170-176
\end{abstract}

\begin{abstract}
For people with disabilities, mobility is important, especially in obtaining public services through the expansion of access to avoid discrimination because of its integral role in participating in social activities. This paper aims to discuss the forms of legal protection and its implementation for persons with disabilities in the Tabanan Regency. Then, it is also intended to explore the conditions of legal guarantee provisions for disabilities related to access to public services. This study is classified as an empirical legal study that uses various methodological approaches, including sociology of law; conceptual, and legislation. Meanwhile, the study data collected were obtained through literature studies, interviews, and observations. In the end, it was discovered that there were adequate provisions regarding regulations that discussed legal protection for persons with disabilities whose rights were targeted in the formation of related laws. Meanwhile, several obstacles faced in the implementation of legal protection related to access to public services, among others, limited awareness of parents with children with disabilities, budget funds, and the lack of professionalism of human resources. Finally, the regulations stipulated on the protection of the human rights of persons with disabilities must be made into a Tabanan district regulation.
\end{abstract}

Keywords: accessibility; legal protection; public service.

\begin{abstract}
Abstrak-Bagi penyandang disabilitas keleluasaan atas mobilitas menjadi hal penting, terkhusus pada perolehan layanan publik lewat perluasan aksesibilitas sehingga terhindarlah mereka dari diskriminsai sebab keutuhan perannya atas partisipasi pada kegiatan sosial. Penelitian ini ditujukan pada pembahasan perihal bagaimana bentuk proteksi hukum dan pelaksanaannya bagi warga kabupaten tabanan yang berkebutuhan khusus. Kemudian, ditargetkan pula pada riset ini perihal kondisi penyelenggaraan penjaminan hukum bagi mereka atas akses terhadap pelayanan public. Riset ini tergolong kepada kajian hukum empiris dimana dimanfaatkan bergumam pendekatan metodologis, antara lain sosiologi hukum, konseptual dan perundangundangan. Sementara, sejumlah data kajian yang terkumpul didapatkan dari studi literatur, wawancara, dan observasi. Didapati hasil pada akhir penelitian yakni berkenaan kepadaan ketetapan aturan yang membahas perlindungan hukum bagi warga disabilitas dimana pelingkupan hak asasi mereka telah terpenuhi pada pencantuman keberlakuan undang-undang terkait. Bagi penyandang disabilitas, ditemui sejumlah hambatan pada pelaksanaan perlindungan hukum atas akses layanan publik terdapat hambatan diantaranya ialah keterbatasan pada kesadaran orang tua dengan anak disabilitas dan anggaran pembiayaan, serta kurangnya profesionalisme sumber daya manusia pelaksananya. Terakhir, aturan yang dibentuk terkait perlindungan hak asasi penyandang disabilitas semestinya dijadikan peraturan kabupaten Tabanan.
\end{abstract}

Kata kunci: aksesibilitas; perlindungan hukum; pelayanan publik. 


\section{Pendahuluan}

Bagi Indonesia, selaku negara kesatuan yang mempunyai keluasan ragam ihwal didalamnya, tidaklah bisa ditinggalkan atau diabaikan kepentingan tiap warganya termasuk bagi warga penyandang disabilitas. Apapun, alasannya mereka haruslah diikutsertakan menjadi bagian perkembangan kehidupan bangsa. Demi tujuan ini, agar mereka bisa menjalankan fungsi sosialnya, perlu ada kekhususan perhatian terhadapnya sebab mereka ialah sama selaku warga yang normal dalam perbuatan, pemikiran, perasaan, dan ideologinya di mana mereka pun mampu menjalankan hal sebagaimana lain khalayak secara umum. Naum disayangkan, seringkali didapati perlakuan yang berbeda bagi penyandang disabilitas. Sebab itu, pemerintah lewat jalur konstitusi menyediakan penjaminan baginya agar tak lagi mendapati kesenjangan partisipasi politik dan kehidupan bermasyarakat, pembatasan, ketertinggalan, pengucilan, dan peminggiran dengan pengaturan Pasal 28H (2) UUD 1945 (UndangUndang Dasar) dimana disebutkan perihal penjaminan atas hak tiap warga tanpa pengecualian untuk mendapati kekhususan perlakuan, kemudahan akses, faedah, kesempatan, dan persamaan demi tercapainya cita-cita bangsa yang berkeadilan. Di ruang public, sudah semestinya disediakan sejumlah kekhususan fasilitas bagi penyandang disabilitas demi keterdukungan bagi partisipasi sosialnya dan sepatutnya ihwal ini mendapati sokongan dari pemerintah dan segenap khalayak yang berdiam dan hidup di Indonesia agar kelak tak lagi ditemui pada lingkungan masyarakat diskriminasi terhadap penyandang disabilitas. Pada keadaan aksesibilitas fasilitas layanan publik ialah isu yang tidak terpisahkan pada penyelenggaraan layanan publik serta sepatutnya dipunyai tiap lembaga pelayan public yang ada demi didapatkannya kemudahan dalam kegiatan pelayanan, terkhusus bagi penyandang disabilitas.

Hal demikian menjadi semakin penting utamanya bagi daerah wisata seperti Kabupaten Tabanan, Bali. Dalam dukungannya, pembenahan sejumlah fasilitas umum di Kabupaten Tabanan telah dijalankan oleh pemerintah lokal setempat. Kebaikan layanan barang/jasa yang disediakan pemerintah lewat kemudahan aksesibilitas, tak ayal lagi, menjadi satu dari faktor pendorong kepesatan tumbuh kembang pembangunan daerah. Hal demikian bertindak selaku satu dari usaha pemerintah dalam pemenuhan kebaikan layanan bagi masyarakat, dimana pada ujungnya akan dirasakan impak nyata pada terpenuhinya kebutuhan dan keinginan masyarakat yang mana kondisi ini menjadi- kan kedapatan atas rasa puas yang muncul di kalangan masyarakat.

Dalam pelaksanaan aktivitas harian masyarakat, kepadaan penyediaan prasarana dan saranan oleh pemerintah menjadi satu pokok kepentingan. Namun, perlu diperhatikan bahwa tidaklah semua masyarakat yang berkunjung ke Tabanan-umumnya berliburmempunyai kesempurnaan kondisi fisik. Maka itu, haruslah pula diperhatikan kepadaan prasaranan dan sarana bagi enyandang disabilitas dengan mempertimbangkan segenap hakhaknya sebab keterbatasan yang dimiliki oleh mereka menjadikannya butuh akan kehususan fasilitas yang mampu menyokong tiap kepentingan dan keperluan warga yang dating maupun berdiam disana (Yaniza Tiza, 2014 8). Berlandaskan isu ini, bagi penulis menarik untuk melakukan kajian pada keterkaitannya dalam tajuk studi pelaksanaan perlindungan hukum bagi penyandang disabilitas dalam mendapatkan pelayanan publik di Kabupaten Tabanan"

Dari isu terbahas sebelumnya, didapati dua pokok persoalan yang dijadikan objek sasaran pada kajian dalam tulisan ini; Bagaimanakah bentuk perlindungan hukum bagi penyandang disabilitas di Kabupaten Tabanan?; Bagaimanakah pelaksanaan perlindungan hukum bagi penyandang disabilitas dalam mendapatkan pelayanan publik di Kabupaten Tabanan?

\section{Metode}

Bahasan penelitian yang dituliskan pada kesempatan ini tergolong pada jenis kajian hukum empiris, yakni penelitian hukum yang dijalankan pada kehendak atas penemuan deskripsi kebenaran dan kenyataan kondisi hukum yang kejadiannya mengambil tempat di antara masyarakat serta selaku jenis kajian dengan keberfungsian mengulik kenyataan norma hukum yang dihidupkan oleh suatu masyarakat pada sebuah lingkungan.

Adapun, pada perkara pendekatannya, peneliti memanfaatkan serangkaian pendekatan, yakni pada konteks sosiologi hukum-berdasar pada pernyataan lisan dan tulisan serta kenyataan perilaku hukum; konseptual, dan undang -undang (Soerjono Soekanto, 2001 51). Kemudian, Kabupaten Tabanan berlaku sebagai tempat pelaksanaan penelitian ini. Sejumlah kumpulan data yang dimanfaatkan pada kajian diperoleh lewat observasi dimana cara ini ditujukan bagi penghimpunan data pada rupa kenyataan yang dapat ditemui pada lokasi demi kelancaran dan kepadaan hasil analisis serta ditambahkan pula sokongan lain data selaku 
penguat temuan yang dapat mengonfirmasi kebenaran akan kenyataan yang didapati pada fakta lapangan dengan melalui wawancara bersama narasumber terkait. Selain itu, penulis juga menggunakan penelitian kepustakaan yaitu dengan membaca dokumen, majalah ilmiah, serta aturan undang-undang berkenaan proteksi hukum teruntuk penyandang disabilitas.

\section{Hasil Penelitian Dan Pembahasan}

\section{Bentuk Perlindungan Hukum Bagi Penyan- dang Disabilitas Di Kabupaten Tabanan.}

Menurut Hadjon, perlindungan hukum adalah perlindungan terhadap harkat dan martabat, serta pengakuan terhadap hak asasi manusia yang dimiliki oleh subjek hukum (Philipus M. Hadjon, 1987 23). Berdasarkan pemahaman ini tujuan pada perlindungan martabat dan harkat juga hak asasi dalam hukum dijalankan dengan pemanfaatan sarana hukum, karenanya haruslah didasari pada maksud terlindunginya martabat dan harkat manusia pada suatu usaha penyelenggaraan perlindungan hukum. Kemudian, pada kasus Indonesia, pandangan ini mengarah pada artian dimana perlindungan masyarakat secara hukum haruslah beracuan dan dilandasi pada norma yang terkandung dalam pancasila.

Bagi segenap bangsa Indonesia, Pancasila dijadikan pedoman hidup selaku kedudukannya sebagai landasan ideologi dan dasar negara. Berkenaan isu kesetaraan dan persamaan perlakuan bagi warganya berbahasa pada rincian cantuman sila ke-lima pancasila dengan bunyi keadilan bagi seluruh rakyat Indonesia yang mana dengan keberlakuan moral ini ditegaskan perihal pengutamaan kesetimbangan atas pemberlakuan kewajiban dan hak bagi segenap warga yang berdiam di Indonesia. Yang dimaksudkan dengan kesetimbangan atau Kesetaraan ialah mengarah pada konteks situasi dalam ragam sistem kemasyarakatan, seperti akomodasi fasilitas publik, akses informasi, kegiatan sosial, dan pelayanan publik maupun pada lain konteks.

Pada paragraf keempat mukadimah UUD 1945 disebutkan bahwa pendirian Indonesia selaku negara ditujukan pada kehendak atas terlindunginya seluruh tumpah darah dan segenap bangsanya. Dalam maknanya, ide ini dikaitkan pada perlindungan atas kebebasan dan penghapusan perbedaan ataupun perlakuan diskriminatif bagi warga negara yang berdiam di Indonesia, dalam keluasan pandangan ini juga berarti persamaan atas kewajiban dan hak dari tiap individu di Indonesia (Ari Atu Dewi Anak
Agung Istri, 2018 50-62). Dengan adanya pokok tujuan ini, terkhusus pada kasus penyandang disabilitas, wajib bagi negara untuk melindungi mereka secara hukum. Pasal 28D (1) UUD 1945 mencantumkan bahwa kesamaan perlakuan, kepastian, perlindungan, penjaminan, dan pengakuan hukum berkeadilan adalah hak dasar setiap orang. Dengan demikian, pada pemahamannya kandungan dan ikatan keteraturan pada pasal ini juga dimaksudkan bagi penyandang disabilitas. Sebab itu menjadi wajib bagi negara untuk bisa memastikan proteksi hukum bagi mereka serta menjamin perolehan atas kesamaan perlakuan hukum baginya selaku usaha pemerintah memenuhi perannya, terkhusus pada ihwal pemenuhan hak penyandang disabilitas dalam kesetaraan.

UU/No.19/2011 tentang pengesahan konvensi hak-hak penyandang disabilitas mengatur ihwal pemenuhan dan Perlindungan hak penyandang disabilitas yang mana didapati pokok substansial dalam prinsipnya, yaitu

1. Terbebasnya dari pelakuan diskriminatif, penyiksaan atau merendahkan martabat bagi segenap penyandang disabilitas.

2. Kewajiban atas penyesuaian aturan undang-undang bagi perlindungan penyandang disabilitas bagi Negara.

3. Kesamaan dalam penjaminan dan perlindungan kebebasan dan hak bagi penyandang disabilitas, dan tak terpisahkan pula penghormatan bagi martabatnya.

4. Pengakuan atas kesamaan hak penyandang disabilitas.

Selanjutnya, dalam lain aturan, yakni UU/ No.8/2016 dicantumkan ihwal terkait pemenuhan dan perlindungan hak penyandang disabilitas dimana diwajibkan atas terlaksananya unit layanan disabilitas, aksesibilitas, pemberdayaan, perlindungan, penghormatan, penghapusan diskriminasi dan kesetaraan kesempatan bagi warga berkebutuhan khusus. Dalam Pasal 8 undang-undang yang dimaksud teratur secara terperinci berkenaan hak perlindungan dan keadilan hukum bagi penyandang disabilitas, dalam cakupan

a. Hak atas penunjukan wakil kepentingan pada ihwal perdata baik diluar pengadilan maupun di luarnya.

b. Hak terlindunginya dari segala pengambilan hak milik/perampasan, diskriminasi, penganiayaan, kekerasan, dan tekanan

c. Perolehan kepadaan akses atas layanan 
peradilan

d. Perolehan kepadaan akses atas layanan jasa non-perbankan dan perbankan e. Hak waris dan kepemilikan harta tidak bergerak dan bergerak

\section{f. Pengakuan selaku subjek hukum} hukum

g.Hak kesamaan perlakuan di depan

Pemerintah Provinsi Bali juga telah menerbitkan peraturan daerah sebagai kewajiban dan dasar terkait penyediaan kepadaan dan proteksi hak penyandang disabilitas yang dicantumkan pada Perda/No.9/2015 tentang Perlindungan Dan Pemenuhan Hak Penyandang Disabilitas. Aturan ini ialah perwujudan kebesaran atensi Pemerintah Daerah Bali pada usaha pemberlakuan tindakan atas pemberian kepadaan dan proteksi hak penyandang disabilitas. Pada Pasal 1 angka 9 aturan yang dimaksud ditegaskan bahwa lindungan dan kepadaan hak penyandang disabilitas adalah mengacu pada segenap aktivitas atau perlakuan yang melindungi dan menjamin hak konstitusional mereka dengan berkesesuaian pada harkat dan martabat kemanusiaanya, disertakan pula penghindaran pada perlakuan diskriminatif dan kekerasan. Kemudian pada Pasal 5 aturan yang sama disebutkan bahwa bentukan kepadaan hak penyandang disabilitas tercakupi pada aspek rehabilitasi, tempat tinggal, penanggulangan bencana, bantuan hukum, politik, pemberitaan, adat dan keagamaan, seni budaya dan olahraga, kesehatan, ketenagakerjaan dan pendidikan.

Haruslah didapati kesamaan perlakuan dan peniadaan diskriminasi sebagaimana bagi khalayak umum dalam Konteks pemenuhan hak penyandang disabilitas. Misalkan pada konteks pemenuhan kepadaan hak dalam konteks pendidikan, wajib adanya penyediaan fasilitas penunjang, seperti pendirian Sekolah Luar Biasa (SLB) di Provinsi Bali selaku usaha pemerintah memenuhi tugasnya pada maskud yang dicantumkan sebelumnya. Diluar daripada penyediaan fasilitas sekolah, pemerintah daerah juga selayaknya menyediakan kecukupan tenaga pendidik dengan kepadaan kualitas profesionalisme. Dalam pencapaian keidealan yang dimaksud haruslah dijalankan program latihan kelompok kerja tenaga pendidik bagi guru di SLB sebagaimana telah dicantumkan aturannya dalam Perda/No.9/2015 Pasal 8 tentang Perlindungan Dan Pemenuhan Hak Penyandang Disabilitas. Sejauh ini, dalam pencapaian lindungan atas hak penyandang disabilitas, belum ada hukum kedaerahan yang dikeluarkan secara khusus oleh Pemerintah Kabupaten Tabanan berkenaan pengaturan pemenuhan hak, perlindungan dan penghormatan penyandang disabilitas di daerah setempat. Pada kesempatan wawancara di Dinas Sosial Kabupaten Tabanan bersama Ibu Eni (seksi pelayanan dan rehabilitasi tuna sosial), didapati fakta ketiadaan produk hukum daerah, berupa perda kabupaten berkenaan kepentingan penyandang disabilitas, akibatnya penyelenggaraan perlindungan bagi penyandang disabilitas masih beracuan pada aturan dalam Perda/No.9/2015 tentang Perlindungan Dan Pemenuhan Hak Penyandang Disabilitas dari pemerintah provinsi serta UU/No. 8/2016 perihal Penyandang Disabilitas dari pemerintah nasional.

\section{Pelaksanaan Perlindungan Hukum bagi Pen- yandang Disabilitas dalam Mendapatkan Pe- layanan Publik Di Kabupaten Tabanan}

Pelayanan publik dalam UU/No.25/2009 didefinisikan selaku serangkaian aktivitas yang dimaksudkan pada pemastian kepadaan kebutuhan layanan atas pelayanan administratif, barang, dan jasa bagi tiap warga negara yang disesuaikan aturan undang-undang dan penyediaannya ialah oleh pelaksana layanan publik. Sepatutnya, tidaklah mendapati pengecualian bagi Penyandang disabilitas atas kenikmatan yang diberikan pada publik melalui sejumlah pelayanan. Pada nyatanya, seringkali keterbatasan akses bagi mereka menjadi pokok persoalan tersendiri dalam konteks ini. Sebagaimana UU/No.8/2016 menyebutkan bahwa aksesibilitas ialah sepenggal aspek kehidupan manusia yang berada pada keutamaan dalam akomodasi kegiatan manusia. Dengan keterbatasan yang menyertai, bagi penyandang disabilitas menjadi sangatlah penting kepadaan aksesibilitas. keberadaan aksesibilitas berada pada maksud pemberian kemudahan pada pelaksanaan kegiatan harian di mana dengannya akan dicapai kesamaan dalam perolehan layanan publik.

Pemberlakuan upaya pemenuhan kebutuhan dasar dan hak penyandang disabilitas lewat sejumlah Dinas terkait oleh Pemerintah daerah Kabupaten Tabanan dijalankan dalam kepaduan atau integrasi. Pada dasarnya adalah sama antara ragam hak dasar orang kebanyakan dan penyandang disabilitas, karenanya usaha pemenuhan akan hal itu senantiasa diupayakan oleh Dinas Sosial. Secara keseluruhan, di Kabupaten Tabanan, upaya pemenuhan kebutuhan dasar dan hak penyandang disabilitas menemui sejumlah hambatan sebagai akibat keberadaan sejumlah persoalan, 
seperti

\section{a. Keterbatasan anggaran pembiayaan.}

b. Keterbatasan sumber daya manusia, dalam hal ini ialah jumlah dan profesionalisme tenaga ahli pelaksana.

c. Perlakuan pada penyandang disabilitas oleh pihak keluarga, yang dimaksud disini adalah kecenderungan perlakuan yang memisahkan penyandang disabilitas dengan sosialnya sebab rasa malu oleh para orang tua dengan anak berkebutuhan khusus.

Oleh Kementerian Sosial Indonesia, dalam aspek rehabilitasi dan layanan sosial, usaha pada pemenuhan hak penyandang disabilitas pun dijalankan, yakni dengan melibatkan unit pelaksana teknis dalam aspek rehabilitasi dan layanan sosial bagi orang berkebutuhan khusus lewat PSBN (Panti Sosial Bina Netra) Mahatmiya. Lembaga ini ditugaskan pada pemberian rehabilitasi sosial, pelayanan, pelatihan, serta bimbingan bagi penyandang disabilitas sehingga mereka bisa hidup mandiri dan mampu meningkatkan kesejahteraan hidupnya.

Kemudian dalam aspek pendidikan, hak yang dimiliki penyandang disabilitas dan wajib atas pemenuhannya tercantum pada UU Penyandang Disabilitas Pasal 40 (3) dimana negara berkewajiban pada penjaminan keikutsertaan penyandang disabilitas pada program wajib belajar dua belas tahun. Dalam usaha pencapaian kewajiban ini pemerintah membentuk sejumlah SLB (Sekolah Luar Biasa) selaku unit belajar yang dikhususkan bagi penyandang disabilitas. Terdapat ragam program pelatihan atas beberapa kemampuan dan keterampilan dasar yang bisa dipelajari di SLB. Adapun, dalam keutamaan tujuannya adalah agar penyandang disabilitas dapat bersosialisasi dan mandiri dalam kehidupan bermasyarakatnya. Namun sangat disayangkan, meski dengan kebaikan kehendak, masih ditemui sejumlah hambatan pada pelaksanaan pendidikan bagi penyandang disabilitas sebab sejumlah ihwal, diantaranya

\section{a. Kurangnya sumber daya manusia}

b. Kurangnya pemahaman orang tua terhadap kondisi si anak tersebut atau kecenderungan perlakuan orang tua yang memisahkan anak penyandang disabilitas dengan lingkungan sosialnya sebab rasa malu.

Pada wawancara bersama Kepala SLB/C Kemala Bhayangkari (Ibu Zuliati) di Kabupaten Tabanan disebutkan walaupun sekolah luar biasa ini tipe $\mathrm{C}$, tetapi tidak menutup kemungkinan untuk menerima siswa yang mengalami gangguan pada cacat mata atau tuna netra dan tuna rungu wicara, siswa yang diterima disekolah ini merupakan anak yang mampu didik dan mampu latih yaitu tentang bina diri dan keterampilan. Adapun, berkenaan hambatan yang dihadapi di lokasi wawancara adalah kurangnya pemahaman orang tua akan kebutuhan anak penyandang disabilitas, dimana SLB dinilai selaku tempat penyembuhan disabilitas serta sumber daya manusia pelaksana yang masih sangat minim. Tidaklah berserah pihak pemerintah meski pada pelaksanaan pendidikan penyandang disabilitas oleh yayasan swasta. Tetaplah bagi mereka didapati BANBEL (Bantuan Belajar), berupa buku, sepatu, dan tas serta Bantuan Operasional Sekolah (BOS) bagi para siswanya.

Disebutkan bahwasanya setiap tenaga kerja memiliki kesetaraan kesempatan dan hak pada penghasilan, perpindahan, perolehan, kelayakan dan pemilihan pekerjaan di dalam maupun luar negeri pada UU/No.13/2003 perihal ketenagakerjaan. Terkait aturan tersebut, selaku masyarakat dengan kesamaan peran, kesempatan, kewajiban, hak dan kedudukan; penyandang disabilitas juga berhak atas perolehan pekerjaan yang kekhususannya diatur pada UU/ No.8/2016 perihal penyandang disabilitas, dalam cakupan berikut

1. Pemerintah, pemerintah daerah, badan usaha milik negara, dan badan usaha milik daerah wajib mempekerjakan paling sedikit $2 \%$ (dua persen) penyandang disabilitas dari jumlah pegawai atau pekerja.

2. Perusahaan swasta wajib mempekerjakan paling sedikit 1\% (satu persen)

penyandang disabilitas dari jumlah pegawai atau pekerja.

Masihlah menjadi penghalang sejumlah perusahaan keterbatasan yang menyertai penyandang disabilitas untuk menjadikannya pekerja. Pada kondisi ini, dalam pemenuhan keperluan hidupnya, penyandang disabilitas mendapat gangguan untuk bisa mandiri. Penyandang disabilitas yang memperoleh pekerjaan akan bisa seutuhnya terlibat pada kegiatan dan lingkungan sosial lewat pertambahan peran, kemandirian, dan keterampilan sosial yang menyertainya.

Untuk bisa mandiri dalam aktivitasnya serta pemenuhan partisipasi sosial sangatlah bermakna bagi penyandang disabilitas pemberian kesempatan dan aksesibilitas dimana dengannya mereka bisa turut berandil dan berinteraksi pada aktivitas sosial kemasyarakatan. Akan didapati 
kemudahan pelaksanaan kegiatan, pelayanan publik, dan mobilitas dengan keberadaan kebaikan aksesibilitas bagi penyandang disabilitas. Kemudian pemenuhan tanggung jawab negara atas kepadaan kebutuhan dasar dan hak penyandang disabilitas akan tergambar pada kepadaan aksesibilitas atas fasilitas di ruang publik bagi mereka hal ini pula akan menjauhkan mereka dari diskriminasi.

Berkenaan aksesibilitas layanan publik, diatur dalam ketegasan pada Pasal 29

UU /No.25/2009 perihal Pelayanan Publik dimana diwajibkan bagi pelaksana atas penyediaan fasilitas, prasarana dan sarana layanan publik pada kekhususan perlakuan yang berkesesuaian sejumlah asas kemudahan dalam pelaksanaan kegiatan bagi penyandang disabilitas.

Merupakan satu pokok kebutuhan bagi penyandang disabilitas, ketersediaan prasarana juga sarana aksesibilitas lingkungan. Kebaikan pada keberfungsian sosial dan perkembangan potensi penyandang disabilitas akan sangat dipengaruhi oleh kebaikan akses yang mereka dapati selaku dukungan baginya. Pada pelaksanaan wawancara di lokasi kajian bersama dengan narasumber penyandang disabilitas (Dewa Gede) didapati sejumlah fasilitas publik yang sangat mendasar sifatnya selaku kebutuhan baginya, yakni penyediaana. Sejumlah rambu jalanan pada lingkungan masyarakat, ataupun sekitaran bangunan dan gedung.

b. Pada bangunan, semestinya dilengkapi dengan pegangan (Ramp) demi kemudahan mobilitas.

c. Pada gedung dengan dual anta atau lebih seharusnya dilengkapi fasilitas eskalator atau lift.

d. Tanda darurat/bahaya dan Pegangan dalam toilet/kamar mandi.

e. Tidaklah dipergunakan jenis lantai yang licin pada bangunan.

f. Toilet/kamar mandi khusus dan jalur khusus penyandang disabilitas.

Perkembangan yang ada di Indonesia, satu diantaranya ialah sebab dukungan oleh kemajuan wilayah pariwisata. Diluar daripada perbaikan dan pengembangan objek wisatanya, kepadaan prasarana dan sarana yang adapun semestinya menjadi perhatian guna dicapainya kenyamanan berwisata bagi para wisatawan. Satu dari bentuk kenyamanan yang dimaksud ialah Aksesibilitas. Di Kabupaten Tabanan, satu dari kawasan wisata kesukaan ialah daerah Tanah Lot . wisatawan maupun khalayak setempat yang berkunjung dan datang tidaklah disertai dengan kesempurnaan fisik pada kesemuanya, sangat dimungkinkan mereka yang berkunjung memiliki kekhususan akan kebutuhannya (disabilitas) sebab ini sejumlah fasilitas dengan kesesuaian pada kekhususan nya sangatlah dibutuhkan bagi mereka yang berkebutuhan khusus. Di kawasan Tanah Lot telah dibangun trotoar, jalanan, dan tempat parkir khusus pada akses lokasi wisata yang diperuntukkan bagi wisatawan dengan disabilitas sebagai bentuk pemenuhan kepadaan kebutuhan dan hak penyandang disabilitas, hanya saja belum didapat kekhususan perhatian bagi penyandang disabilitas pada toilet yang yang ada di kawasan wisata Tanah Lot.

Penghormatan dan pemenuhan sejumlah hak penyandang disabilitas dapat dijalankan dengan penyediaan aksesibilitas terhadap fasilitas ataupun sarana layanan publik. Akan didapati kemudahan mobilitas dan aktifitas bag penyandang disabilitas bilamana didapati kepadaan akses di Lingkungan sekitarnya, sekaligus, hal ini juga akan menjadikan atasnya elemen penyokong pada dukungan akan kesuksesan perkembangan dan keutuhan peran ataupun potensi diri penyandang disabilitas secara sosial dalam kehidupan berbangsa. Bernegara dan bermasyarakat (Hikmawati Eny dan Rusmiyati Chatarina, 2011 29).

\section{Simpulan}

Berdasarkan dari penguraian sebelum ini, dapat ditarik simpulan oleh penulis selaku jawaban atas persoalan yang terumuskan sebelumnya. Perlindungan hukum terhadap penyandang disabilitas dalam tatanan kebijakan dan regulasi negara sudah cukup memadai yang ditandai dengan berbagai peraturan perundangundangan yang berlaku dalam pemenuhan hakhak dasar penyandang disabilitas. Tetapi pemerintah Kabupaten Tabanan dalam pemenuhan hak dan perlindungan hukum belum ada perda secara khusus yang mengatur tentang penyandang disabilitas, masih mengacu pada Undang-Undang Nomor 8 Tahun 2016 Tentang Penyandang Disabilitas. Tanggung jawab negara untuk memenuhi hak dasar penyandang disabilitas telah menjamin dan melindungi aksesibilitas terhadap fasilitas publik bagi penyandang disabilitas yang bertujuan untuk mewujudkan taraf hidup penyandang disabilitas yang berkualitas, adil, sejahtera lahir dan batin, bermartabat, dan melindungi penyandang disabilitas dari penelantaran dan eksploitasi, pelecehan dan segala tindakan diskriminatif, 
serta pelanggaran hak asasi manusia.

Pelaksanaan perlindungan hukum bagi penyandang disabilitas dalam mendapatkan pelayanan publik di Kabupaten Tabanan menemui beberapa hambatan yaitu anggaran atau modal yang terbatas, sumber daya manusia yang belum kompeten dalam menangani penyandang disabilitas, peraturan yang belum spesifik mengenai kebutuhan penyandang disabilitas, permintaan yang rendah, dan peraturan yang belum tegas untuk pengupayaan penyediaan fasilitas khusus bagi penyandang disabilitas. Pemenuhan aksesibilitas dalam setiap fasilitas publik di Kabupaten Tabanan sudah dilaksanakan tetapi masih kurang efektif atau kurang perhatian terhadap perawatan fasilitasfasilitas khusus bagi penyandang disabilitas.

\section{Daftar Pustaka}

Dewi, A, A, A, A, I. (2018). Aspek Yuridis Perlindungan Hukum Dan Pemenuhan Hak Penyandang Disabilitas. Jurnal Pandecta. Vol. 13, No. 1.

Eny, H., Chatarina, R. (2011). Kebutuhan Pelayanan Sosial Penyandang Cacat. Jurnal Inovatif. Vol. 16, No. 1.

Hadjon, P. M. (1987). Perlindungan Hukum Bagi Rakyat Indonesia. Surabaya: Bina Ilmu.

Soekanto, S. (2001). Sosiologi Suatu Pengantar. Jakarta: Raja Grafindo Persada.

Tiza, Y. (2014). Analisa Yuridis Terhadap Undang-Undang Nomor 28 Tahun 2002 Tentang Bangunan Hubungannya Dengan Perlindungan Bagi Konsumen Berkebutuhan Khusus (Disabilitas) Di Hotel (Suatu Tinjauan Dari Perspektif Hukum Perlindungan Konsumen), Jurnal Nestor Magister Hukum. 